\title{
Efficiency of coated urea on nutrient uptake and maize production
}

\begin{abstract}
A field experiment was conducted to study the effects of coated urea with urease inhibitor [copper $(\mathrm{Cu})$ and zinc $(\mathrm{Zn})$ ], nitrification inhibitor (DMPP), biochar and geopolymer on ammonium, nitrate, $\mathrm{Cu}, \mathrm{Zn}$ content and crop yield of maize. The treatments were composed of urea alone (control), urea coated $\mathrm{Cu}$ and $\mathrm{Zn}(\mathrm{UCuZn})$, urea coated with $\mathrm{Cu}, \mathrm{Zn}$, and DMPP (UCuZnDMPP), urea impregnated with biochar (Ubio) and urea coated with geopolymer (Ug2). Data showed that treatments with $\mathrm{Cu}, \mathrm{Zn}$, and DMPP produced lower ammonium $\left(\mathrm{NH}_{4}\right)$ and nitrate $\left(\mathrm{NO}_{3}\right)$ in $\mathrm{UCuZn}$ and UCuZnDMPP while they had the highest concentration of $\mathrm{Cu}$ and $\mathrm{Zn}$ in soil and plant tissues. Plots treated with UCuZn and UCuZnDMPP produced maximum $\mathrm{N}$ concentrations in grains and yield, with increases by $79.5 \%$ and $74.1 \%$, respectively, as compared with urea (control). This finding demonstrates that by slow down the hydrolysis and nitrification process using urease and nitrification inhibitor were beneficial to increased $\mathrm{N}$ uptake, ultimately produced higher yield.
\end{abstract}

Keyword: Biochar; Copper; DMPP; Field; Geopolymer; Yield; Zinc 